\title{
Net-Shape Clay Ceramics with Glass Waste Additive
}

\author{
Chantale Njiomou Djangang1*, Elie Kamseu2,3, Antoine Elimbi', Gisèle Laure Lecomte4, \\ Philippe Blanchart ${ }^{4}$ \\ ${ }^{1}$ Department of Inorganic Chemistry, University of Yaounde I, Yaounde, Cameroon \\ "Department of Engineering "Enzo Ferrari”, University of Modena and Reggio Emilia, Modena, Italy \\ ${ }^{3}$ LAM, Local Materials Promotion Authority/MIPROMALO, Yaounde, Cameroon \\ ${ }^{4} \mathrm{GEMH}, \mathrm{ENSCl}$, Limoges, France \\ Email: ${ }^{*}$ djangangc@yahoo.fr
}

Received 26 April 2014; revised 25 May 2014; accepted 11 June 2014

Copyright (C) 2014 by authors and Scientific Research Publishing Inc.

This work is licensed under the Creative Commons Attribution International License (CC BY).

http://creativecommons.org/licenses/by/4.0/

(c) (i) Open Access

\section{Abstract}

In this paper, a glass powder from waste containers was mixed (10 - 40 wt.\%) with a kaolinitic sandy clay from Cameroon to elaborate net-shape ceramics, fired at $1100^{\circ} \mathrm{C}$. The sintering behavior was from dilatometry and thermo gravimetric analyses together with the characterization of porosity and flexural strength. The increase of glass to kaolinite ratio reduces the sintering shrinkage leading to a none-densification sintering when $40 \mathrm{wt} \%$ of glass is added in the mixture. The volume variation during the whole firing process is from the individual volume variations during the quartz transformation, the structural reorganization of kaolinite and during sintering. Quartz size and relative quantity have a significant role on the first processes since it leads to either cohesive or un-cohesive behavior. But the glass quantity strongly controls the second and the third thermal processes because glass additions change the recrystallization processes, leading to the formation of dense clay-glass agglomerates distributed within the three dimensional quartz network.

\section{Keywords}

Clay, Waste Glass Powder, Sintering, Composite, Cameroon

\section{Introduction}

Over the world, very large quantities of wasted glass must receive a careful consideration against environmental issues. In general, wasted glasses are recycled into new glass items to reduce the release of atmospheric carbon

\footnotetext{
${ }^{*}$ Corresponding author.
}

How to cite this paper: Djangang, C.N., Kamseu, E., Elimbi, A., Lecomte, G.L. and Blanchart, P. (2014) Net-Shape Clay Ceramics with Glass Waste Additive. Materials Sciences and Applications, 5, 592-602. 
dioxide. Powders of wasted glasses can replace a ceramic component, acting as a flux in silicate compositions instead of feldspar or other mineral fluxes, to save energy in manufacturing processes [1] [2].

Wasted glasses in mineral mixtures induce a liquid phase sintering process above $900^{\circ} \mathrm{C}$, resulting in higher density and lower water absorption [3]. The role of such addition was extensively experimented in porcelain, in stoneware, in earthenware, and in clay ceramics [4] [5]. It proves that wasted glasses replacing alkaline feldspars have an efficient fluxing behavior in ceramic mixtures since it accelerates the densification process [6] [7]. Published results also indicate that macroscopic mechanical and physical properties are improved with small amounts of glass powder, below $10 \mathrm{wt} . \%$. In many cases, it should be kept below $5 \mathrm{wt} \%$, depending on the characteristics of clay mixtures, to prevent strong variations of process-related behaviors as rheology or dry strength [5].

The accentuated fluxing behavior of glasses is evidenced by the lowering of viscosity related to temperature of wasted glasses in comparison to that of melted orthoclase or albite, in the temperature range used for firing silicate ceramics [8]. But glass viscosity is highly related to the chemical composition, which is easily changed by diffusion at high temperature from neighboring components in the powder compact [9].

In silicate ceramics, changes with temperature of physical behaviors are strongly microstructural dependant. Silicate ceramics often present a granular composite microstructure, with relatively large hard particles distributed in a fine grains ceramic matrix. The rigid network of hard particles induces local constrains in the matrix and at the inclusion-matrix interfaces, reducing the sintering shrinkage and changing the physical properties as porosity and strength [10]-[12]. But the sintering process is different when local stresses are relaxed in the matrix from high temperature creep that is supposed to occur when efficient fluxing additives are used in compositions [13]-[16].

Most published studies presenting experimental results of the sintering shrinkage of granular ceramic composites evidence complex behaviors that are related to grain and matrix phase quantities and compositions. With glass and ceramic powder mixtures, possible theoretical approaches were recently published for predicting the sintering behavior including the role of non-densifying heterogeneities [17] [18]. These studies were more or less validated by experiments with ceramics having simple composition domains, low number of components and very limited grain size and shape distributions. Nevertheless, most of ceramics behave in a very complex way with temperature and it is necessary to experiment on their behavior in detail, to provide very useful data for refining the theoretical approaches.

In this study, we experimented on the thermal behavior of composite ceramics containing large quartz grains mixed with clay and wasted glass. Such ceramic is typically used to manufacture building materials extensively used over the world. Whereas the simple composition, we evidence a complex behavior during sintering depending on each component contents. Clay and quartz are very common components of such materials, and glass addition is the opportunity to reuse it at a large scale.

\section{Materials and Methods}

We used a raw kaolinitic clay (labeled ADI clay from Dibamba, Cameroon), associated with quartz and small quantities of goethite and anatase (Figure 1). The chemical composition of Table 1 obtained by ICP analysis indicates a high $\mathrm{SiO}_{2}$ and a low $\mathrm{Al}_{2} \mathrm{O}_{3}$ contents, with a $\mathrm{SiO}_{2} / \mathrm{Al}_{2} \mathrm{O}_{3}$ molar ratio of 5.19 which classifies the clay as siliceous fireclay [19]. The fluxing alkali oxides $\left(\mathrm{Na}_{2} \mathrm{O}, \mathrm{K}_{2} \mathrm{O}\right)$ and alkaline earths oxides $(\mathrm{CaO}, \mathrm{MgO})$ are low confirming the refractory behavior. The coloring oxides, as $\mathrm{Fe}_{2} \mathrm{O}_{3}$ are in sufficient quantity to gives a light color.

For modified compositions, ADI clay was mixed with a powder glass (labeled GP glass), obtained by crushing, ball milling and screening at $63 \mu \mathrm{m}$ wasted glass containers. The glass melting point is about $700^{\circ} \mathrm{C}$ and Table 1 gives the chemical composition which classifies it as of soda-lime glass. It leads to the calculation of the viscosity variation with temperature, using the Alexander Fluegel simulation method [20]. The parameters of the usual VFT viscosity model in the temperature range of $550^{\circ} \mathrm{C}-1450^{\circ} \mathrm{C}$ are: $\mathrm{A}=-2.5988 ; \mathrm{B}=4288.761$; To $=273.761^{\circ} \mathrm{C}$. These data are important for the understanding of the high temperature behavior of glass-clay mixtures.

For all materials, the identification of mineral phases was made by X-ray diffraction (Bruker D8 Advance with $\mathrm{Cu} \mathrm{K} \alpha 1$ radiation). Bulk densities of 2.63 and $2.62 \mathrm{~g} \cdot \mathrm{cm}^{-3}$ for ADI clay and GP glass respectively were measured with an AccuPyc 1330 Micromeritics picnometer. The size distributions of starting materials were performed by laser diffraction with a Matersizer 2000 Malvern. The difference of particle size is seen in Figure 2, where GP glass particles are essentially within a narrow size interval of $0.7-300 \mu \mathrm{m}$, while those of ADI clay 
Table 1. Chemical compositions of starting materials.

\begin{tabular}{|c|c|c|c|c|c|c|c|c|c|c|}
\hline $\begin{array}{c}\text { Oxides } \\
\text { wt. } \%\end{array}$ & $\mathrm{SiO}_{2}$ & $\mathbf{A l}_{2} \mathbf{O}_{3}$ & $\mathrm{Fe}_{2} \mathrm{O}_{3}$ & MgO & $\mathrm{CaO}$ & $\mathrm{Na}_{2} \mathrm{O}$ & $\mathbf{K}_{2} \mathbf{O}$ & $\mathrm{TiO}_{2}$ & $\mathrm{SO}_{3}$ & LOI \\
\hline ADI Clay & 76.06 & 14.65 & 2.04 & 0.1 & 0.08 & 0 & 0.11 & LD & - & 8.04 \\
\hline GP Glass & 73.85 & 1.28 & 0.04 & 0.21 & 11.05 & 12.98 & 1.1 & 0.09 & 0.21 & 0.28 \\
\hline
\end{tabular}

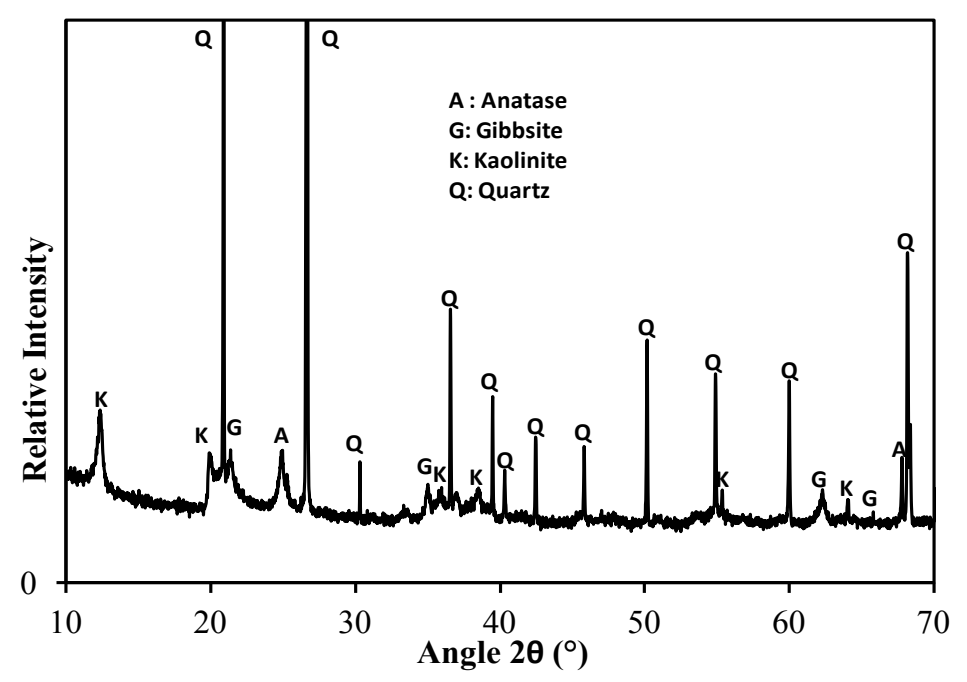

Figure 1. X-ray diffraction pattern of ADI clay.

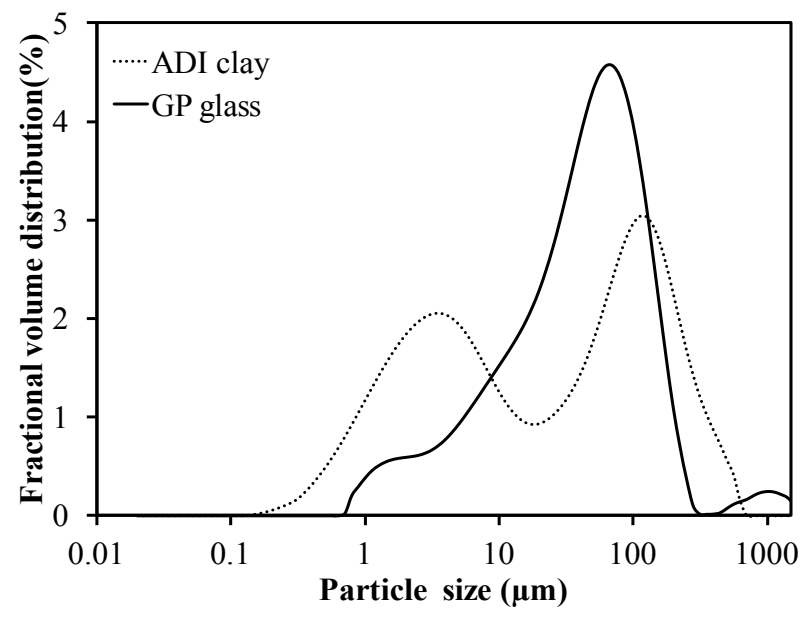

Figure 2. Particle size distribution of ADI clay and GP glass powders.

present a large and bimodal distribution centered at 3 and $120 \mu \mathrm{m}$. This likely heterogeneous size distribution of the two components in the mixture is favorable to increase the green density during shaping. The two raw materials were mixed by ball milling. Various proportions of 0 - $40 \mathrm{wt} . \%$ of glass were added to the clay (Table 2). An additional mixture containing $40 \mathrm{wt} . \%$ of the fine fraction of the clay (labeled FF, $\varnothing<10 \mu \mathrm{m}$ ), instead of glass was considered to exhibit the role of the clay minerals in the raw clay. It is acceptable since clay minerals of ADI are mostly in the fine fraction whereas a remaining $\alpha$-quartz fine fraction $(\sim 24 \mathrm{wt} . \%)$ is evidenced below $10 \mu \mathrm{m}$ in the large particle size distribution of ADI (Figure 2).

The sintering behavior of the different mixtures was studied by optical dilatometry (Misura), and simultaneous differential thermal analyses and thermo gravimetric analyses (DTA-TG Setaram Setsys), up to $1100^{\circ} \mathrm{C}$ with a heating rate of $6^{\circ} \mathrm{C} \cdot \mathrm{min}^{-1}$. 
Table 2. Semi quantitative mineralogical compositions of green mixtures.

\begin{tabular}{|c|c|c|c|c|c|}
\hline Mixture (wt.\%) & & & & & \\
\hline ADI Clay & 100 & 90 & 70 & 60 & 60 \\
\hline Glass Powder $(G P)$ & 0 & 10 & 30 & 40 & / \\
\hline Fine Fraction of ADI Clay $(F F, \varnothing<10 \mu \mathrm{m})$ & / & / & / & / & 40 \\
\hline Kaolinite & 33.73 & 30.04 & 23.61 & 20.24 & 52.52 \\
\hline Quartz & 49.73 & 44.76 & 34.81 & 29.84 & 24.32 \\
\hline Others Minerals (Gibbsite, Hematite, Goethite) & 16.54 & 14.89 & 11.59 & 11.58 & 24.16 \\
\hline
\end{tabular}

For shaping cylindrical samples by uni-axial pressing at $2.5 \mathrm{MPa}$ in a $10 \mathrm{~mm}$ diameter mold, water was added to form plastic pastes with $16 \mathrm{wt} . \%$ of moisture. After drying at $110^{\circ} \mathrm{C}(24 \mathrm{~h})$, samples were fired in an electrical kiln under air at $1100^{\circ} \mathrm{C}$, with a heating rate of $6^{\circ} \mathrm{C} \cdot \mathrm{min}^{-1}$ and a $30 \mathrm{~min}$ dwell time at the peak temperature. Sintered samples were characterized by the bulk density, open porosity by the Archimedes's method and the compressive strength (J.J. instrument). Microstructures were observed by Scanning Electron Microscopy (SEM Stereoscan 260; Cambridge instruments), equipped with a PGT-prism energy dispersive X-ray spectroscopy (EDS) analyzer. Finally, structural analyses of grounded materials were performed by DRX (Bruker D8 Advance).

\section{Results}

The semi-quantitative mineralogical composition of the mixture as function of the amount of GP glass powder is in Table 2. It is calculated considering chemical analyses of Table 1 and chemical compositions of minerals. Complementary information is given by weight loss on TG analyses of Figure 3, where variations are seen at $280^{\circ} \mathrm{C}-300^{\circ} \mathrm{C}$ for gibbsite dehydroxylation and at $450^{\circ} \mathrm{C}-550^{\circ} \mathrm{C}$ for kaolinite dehydroxylation. Considering the amount of added quartz from ADI clay and the added quartz to mixtures, it can be assumed that quartz in ADI have the lowest size particles $(<10 \mu \mathrm{m})$. The finer quartz is assumed to contribute to the densification process during firing whereas the larger size quartz has a filler role in the body mixture.

The sintering behavior is described in Figure 4(a), where densification curves of the clay alone (ADI) and the 3 clay-glass + clay-quartz mixtures (Table 2) are plotted as a function of temperature. Densification rates together with the densification as function of time are shown on Figure 4(b) and the behavior during the dwell time at the peak temperature are on Figure 4(c). It is shown that densification is decreasing with the amount of the glass powder and tends to a very low value for the mixture with $40 \mathrm{wt} . \%$ of glass powder.

XRD patterns of clay alone after firing at $1100^{\circ} \mathrm{C}$ in comparison with that of the mixture 60 wt. $\%$ ADI clay40 wt.\% GP glass powder are given in Figure 5. In the two diffraction patterns we observe the presence of the same major phases of quartz, mullite and hematite. It indicates that the glass powder, even melted, has a limited chemical interaction with the clay during firing. A small difference observed is the appearance of anorthite peaks in the ceramics from mixture, which proves the occurrence a limited clay-glass interaction. Mullite peaks were found to be more intense in the clay product than in the mixture, indicating the inhibiting role of the melted glass in the mullite formation.

Microstructures of the clay fired pelletsare presented in Figure 6. Figure 6(a) enlightens the homogeneous packing of large quartz particles having various sizes, and a clay matrix material at grain boundaries. It leads to entrapped porosity at quartz-clay interfaces. The addition of a higher quantity of kaolinite in the matrix phase (Figure 6(b), Figure 6(c)) leads to a similar matrix-grains arrangement, whereas an accentuated densification is noticeable in the matrix phase, leading the accentuation of entrapped porosity at quartz-clay interfaces. An accentuated matrix densification is also observed with the addition of glass in the matrix phase (Figure 6(c)), but evidencing the preferential densification of small volume of packed clay-glass at large quartz grain interfaces. The role of the big quartz network (Figure 6(a), Figure 6(d)) and that of the large and densified clay-glass agglomerates (Figure 6(b), Figure 6(c)) in a skeleton formation is evidenced. But all compositions show a cracked matrix phase due to the preferential densification of the matrix phase, leading to the presence of an accentuated porosity at interfaces.

The bulk densities of green samples together with those of fired pellets are plotted in Figure 7 . It shows that density decreases with the increase of the amount of glass, but mainly for glass powder content above $10 \mathrm{wt} . \%$. Since we maintained constant parameters related to the pressing process for pellet shaping, the green density 


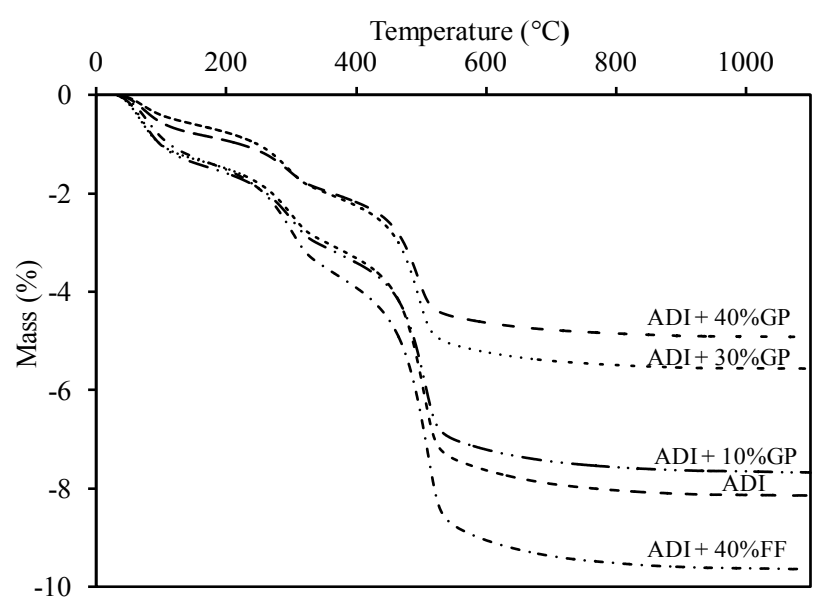

Figure 3. Thermo-gravimetric analyses of clay and clay-quartz mixtures.

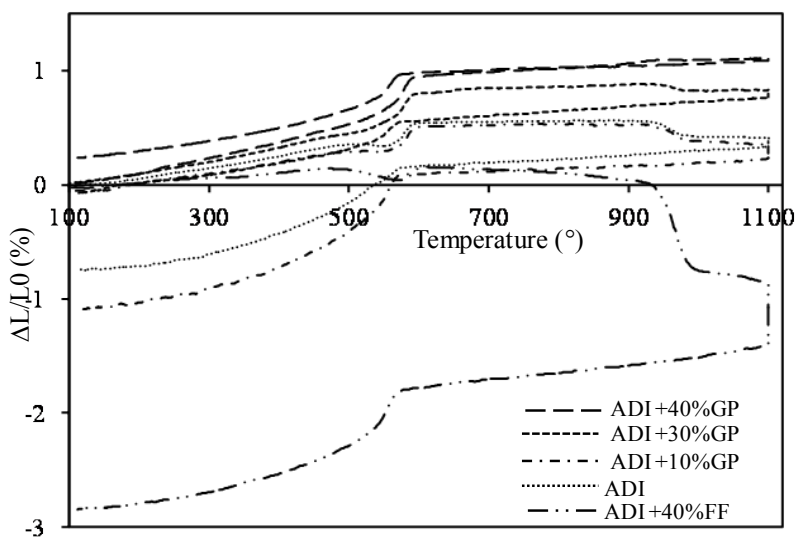

(a)

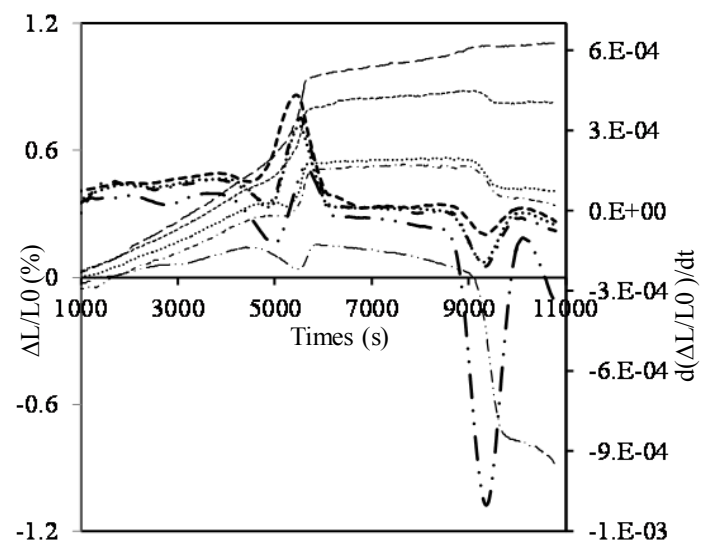

(b)

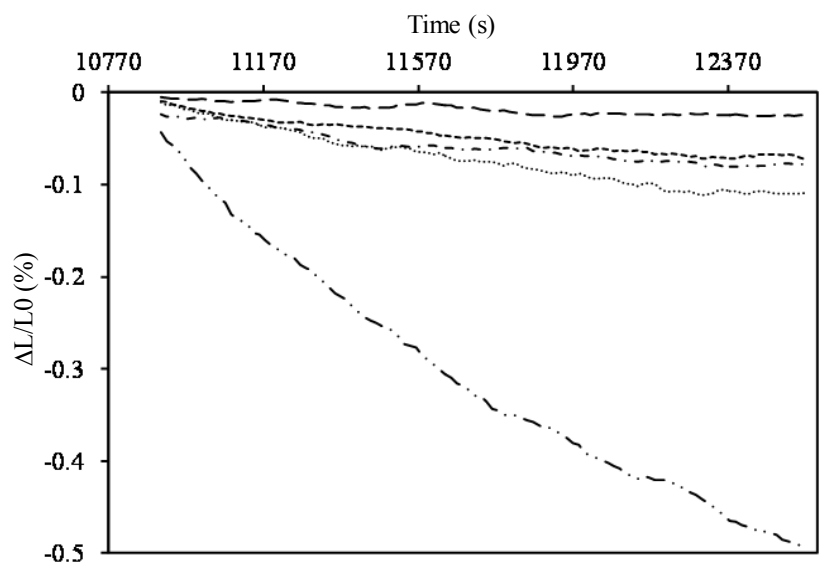

(c)

Figure 4. Dilatometric analyses of clay and clay-quartz mixture at $1100^{\circ} \mathrm{C}$ : (a) shrinkage as function of temperature, (b) shrinkage and sintering rate as function of time, (c) behavior during the dwell time.

is mostly related to the particle size distributions and the relative quantities of components. During firing, the bulk density increase with the firing temperature, but both the ADI clay and the clay-glass mixtures present a limited variation while the ADI clay and the ADI with the added clay fine fraction exhibit a sharp increase of density. 


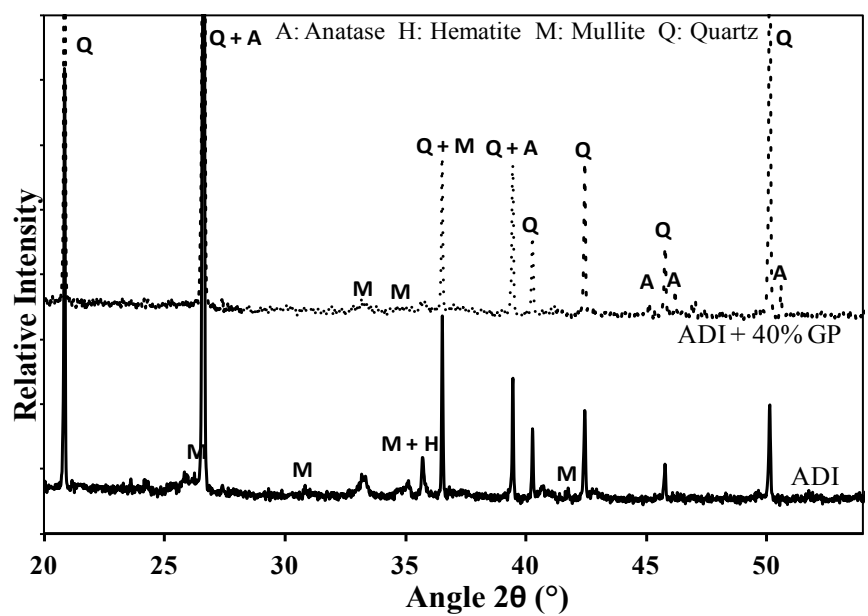

Figure 5. X-ray diffraction patterns of fired mixture at $1100^{\circ} \mathrm{C}$ : A (Anorthite); M (Mullite); Q (Quartz).

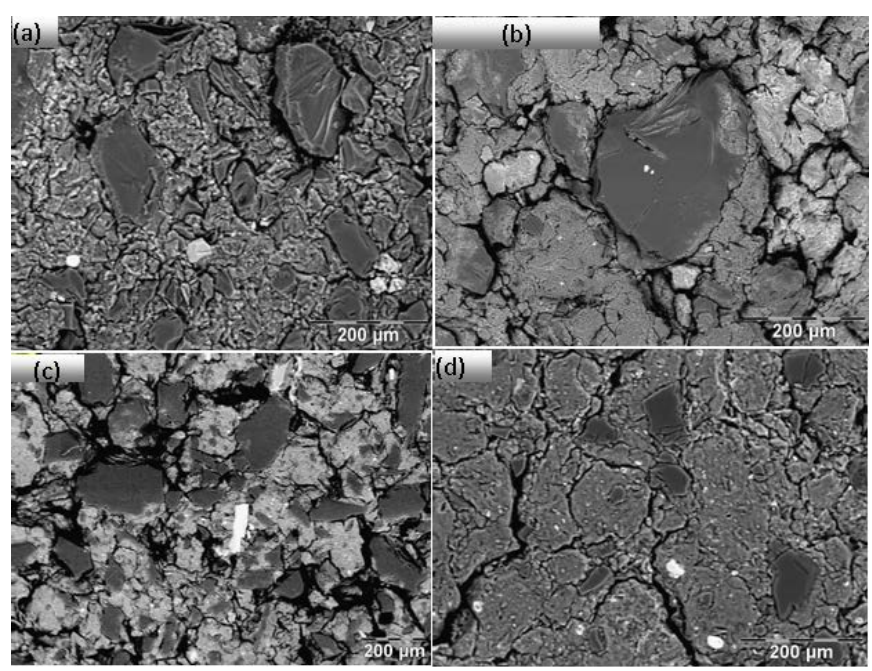

Figure 6. SEM micrographs of fired mixtures at $1100^{\circ} \mathrm{C}$ (a) ADI clay, (b) 90 wt.\% ADI + 10 wt.\% GP, (c) 60 wt.\% ADI + 40 wt.\% GP, (d) 60 wt.\% ADI + 40 wt. $\%$ FF.

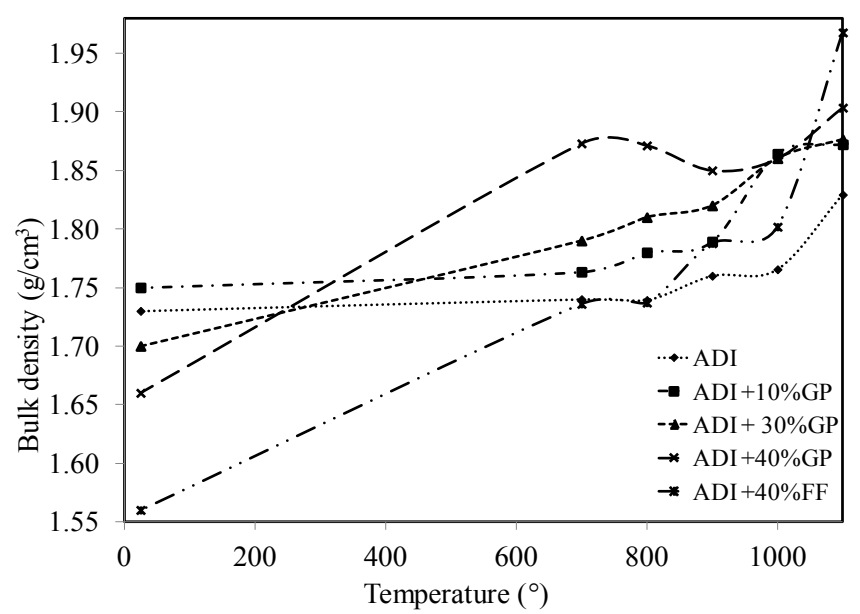

Figure 7. Bulk density of ceramics as function of firing temperature. 
Results also indicate that fired densities are not related to green densities since the mixtures containing either glass or the fine fraction present the highest fired densities whereas their lowest green densities.

The decrease of the open porosity with the increase of the glass content and the firing temperature for all formulations are shown on Figure 8. Porosity variation is linked to the sintering process during firing under the influence of either clay or glass thermal transformations [21]. ADI clay presents a continuous decrease of porosity which is further accentuated above $1000^{\circ} \mathrm{C}$ when the finer clay fraction is added. When glass is mixed to clay, the porosity reduction is limited for $10-30 \mathrm{wt} . \%$ of glass powder, showing the effective clay-glass interaction below $1000^{\circ} \mathrm{C}$. A similar trend is seen with the $40 \mathrm{wt} . \%$ of glass powder sample up to $800^{\circ} \mathrm{C}$, but above an accentuated decrease of porosity occurs up to $1000^{\circ} \mathrm{C}$.

The compressive strengths of ceramics fired at $1100^{\circ} \mathrm{C}$ are reported in Table 3 , for the different compositions. It shows that values are similar to frequently encountered values for ceramic building materials [22]. In general, strengths are increased with glass addition. From Figure 7, strengths are also correlated with the decrease of porosity, since the $60 \mathrm{wt} . \% \mathrm{ADI}+40 \mathrm{wt} . \%$ GP sample presents the lowest porosity value.

\section{Discussion}

Microstructures of Figures 6(a)-(d) show the typical aspect of clay-quartz mixtures with microcomposite microstructures [23]. The large quartz grains are embedded within the clay matrix phase, but the finer fraction of quartz is also distributed within the clay matrix. With clay-glass materials, a similar aspect is seen, but the glass fraction is obviously distributed within the matrix phase and therefore associated with the clay and the finer quartz fraction.

Figure 1 evidences that ADI clay contains mostly the clay mineral kaolinite associated with a significant quartz quantity. Minor minerals are anatase and mostly goethite. The particle size distribution of Figure 2 reflects the quartz size in ADI since the small fraction of the bimodal distribution (average of $2.5 \mu \mathrm{m}$ ) can be attributed to kaolinite and the larger fraction (average of $150 \mu \mathrm{m}$ ) is certainly from quartz. The accentuated bimodal curve reflects the size distribution of quartz which range from 20 to $700 \mu \mathrm{m}$.

The GP glass powder has an average grain size of $90 \mu \mathrm{m}$ and a very large size distribution from 0.9 to $300 \mu \mathrm{m}$. Such a very large size distribution is favorable to different glass roles in the ceramic at high temperature since the finer fraction will interact easily with the mixture whereas the larger fraction will act as an added mineral charge.

As a consequence of the mineralogical composition, the thermogravimetric curves of Figure 3 present typical variations at $250^{\circ} \mathrm{C}-300^{\circ} \mathrm{C}$ and at $450^{\circ} \mathrm{C}-550^{\circ} \mathrm{C}$. They are from goethite and kaolinite dehydroxylation respectively, and the extend of the higher temperature mass loss is related to the kaolinite content. For ADI, the kaolinite quantity is 33.73 that decreases to 20.24 for ADI mixed to 40 of GP glass. Such mass variation occurs in the clay fraction, which is the main component of the matrix phase of the microcomposite (Figure 6).

During sintering, all dilatometric curves show successive volume variations: 1) thermal expansion of materials below $550^{\circ} \mathrm{C} ; 2$ ) at $450^{\circ} \mathrm{C}-600^{\circ} \mathrm{C}$, a densification from kaolinite dehydroxylation; 3) a typical variation at $573^{\circ} \mathrm{C}$, from the reversible $\alpha$ to $\beta$ quartz structural transformation; 4) above $600^{\circ} \mathrm{C}$, a very limited densification which can compensate a small shrinkage; 5) at $960^{\circ} \mathrm{C}-980^{\circ} \mathrm{C}$, a densification from the structural reorganization of kaolinite; 6) a final densification during the temperature stage at $1100^{\circ} \mathrm{C}$.

From Figures 4(a)-(c), both the reversible quartz transformation, the structural reorganization process of kaolinite and the sintering shrinkage contributes to the global densification during the complete firing process. The extend of individual volume variation depends on components contents in the composition: glass; kaolinite; fine quartz; large quartz grains fraction.

The quartz role at $573^{\circ} \mathrm{C}$ on both expansion during heating and shrinkage during cooling is illustrated in Figure 9, which is the interpretation of dilatometry of Figure 4(a). It is seen that the role of quartz content is strongly correlated to glass content. At higher quartz content (50 wt.\%) and no glass addition, the heating expansion is low and is significantly exceeded by the cooling shrinkage. This trend is strongly accentuated for 45 wt. $\%$ of quartz and $10 \mathrm{wt} . \%$ of glass (Table 2). It is due to the low cohesion of large quartz grains during heating the powder compact below $600^{\circ} \mathrm{C}$, where no grain bridging occurs by sintering. During cooling after sintering at $1100^{\circ} \mathrm{C}$ the occurrence of quartz grain bridging is evidenced since the accentuated shrinkage at $573^{\circ} \mathrm{C}$. This trend is accentuated by the small glass content of $10 \mathrm{wt} . \%$. 
Table 3. Compressive strengths of fired samples against compositions.

\begin{tabular}{ccccc}
\hline \multicolumn{5}{c}{ Mixture } \\
\multirow{2}{*}{ wt.\% } & ADI clay & 90 & 70 & 60 \\
& Glass powder (GP) & 10 & 30 & 40 \\
$\sigma(\mathrm{Mpa})$ & & 10.49 & 11.20 & 12.68 \\
\hline
\end{tabular}

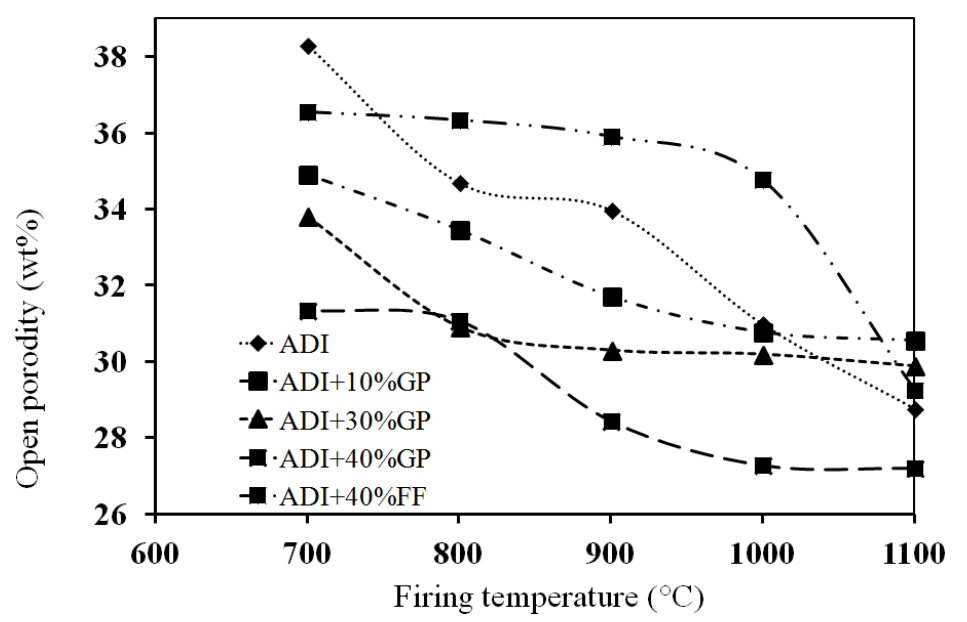

Figure 8. Open porosity of ceramics as function of firing temperature.

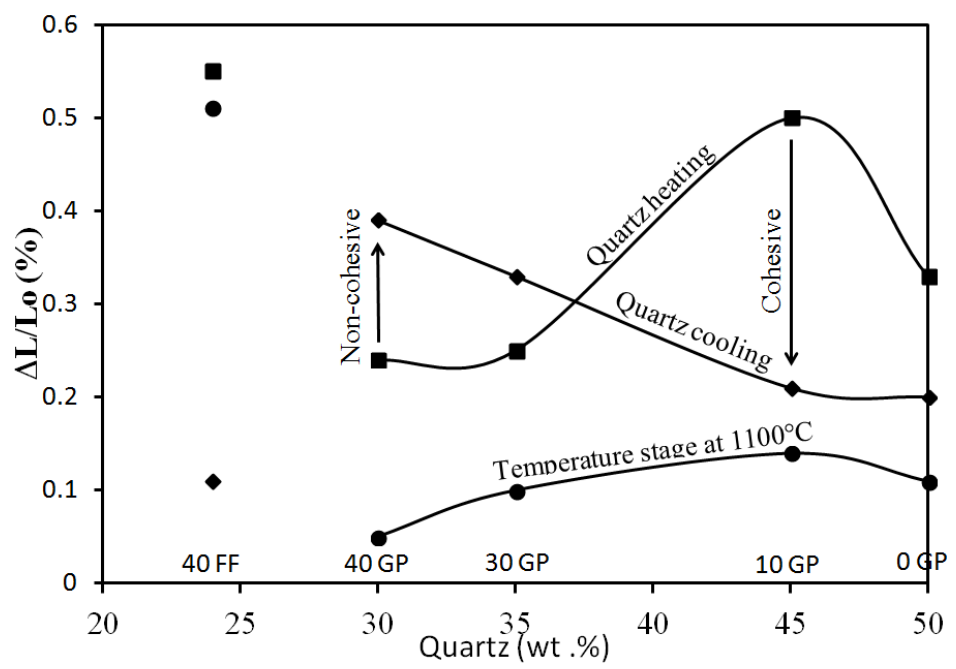

Figure 9. Dilatometry variations against composition at $573^{\circ} \mathrm{C}$ during heating (square) and cooling (lozenge), and at $1100^{\circ} \mathrm{C}$ during the temperature stage (circle).

The cohesive behavior at high quartz and low glass contents shift to an un-cohesive behavior at low quartz content (35 - $30 \mathrm{wt} . \%$ ) and higher glass content (30 - $40 \mathrm{wt} . \%)$. The heating expansion is higher than the cooling shrinkage, meaning the limitation of grain bridging after sintering at $1100^{\circ} \mathrm{C}$, even through the glass content is 30 - $40 \mathrm{wt} . \%$. In a different way, the replacement of $40 \mathrm{wt} . \%$ of glass by kaolinite mineral (sample $40 \mathrm{wt} . \% \mathrm{FF}$ containing the fine fraction of ADI clay, below $5 \mu \mathrm{m}$ ), leads to a very cohesive behavior since the cooling shrinkage $(0.54 \%)$ exceeds significantly the heating expansion $(0.11 \%)$. It further evidences the very specific behavior of glass addition on thermal transformations.

From dilatometry curves and the limited sintering temperature of $1150^{\circ} \mathrm{C}$, we assume that large quartz grains are inert during heating, and that a limited interaction between quartz and matrix phases occurs due to diffusion, 
mostly when glass is added. During cooling, local stresses occur because differences in thermal dilatations between different phases. It contributes to either cohesive or un-cohesive behaviors, depending in the clay/glass ratio within the matrix phase and in the kaolinite content (Figures 4(a)-(c)).

At temperatures between the quartz variation at $573^{\circ} \mathrm{C}$ and the shrinkage densification at $1100^{\circ} \mathrm{C}$, a third densification occurs during heating at $960^{\circ} \mathrm{C}-980^{\circ} \mathrm{C}$, which is from the structural reorganization process of kaolinite [24]. Dilatometric curves on Figures 4(a)-(c) show a reduction of this densification with the relative kaolinite content since it attains $0.7 \%$ for 52, $52 \mathrm{wt} . \%$ of kaolinite (sample $40 \mathrm{wt} . \% \mathrm{FF}$ ) and tends to zero for 20.24 wt.\% of kaolinite (sample 40 wt.\% GP). It is from the glass interaction with dehydoxylated kaolinite, below $950^{\circ} \mathrm{C}$, since the relatively low glass viscosity in the $800^{\circ} \mathrm{C}-950^{\circ} \mathrm{C}$ temperature range $\left(10^{5}-10^{3} \mathrm{~Pa} . \mathrm{s}\right.$ from the VFT model) [9] and the very high specific surface and reactivity of metakaolinite [25]. When glass to kaolinite ratio is increased, we assume the modification of the structural reorganization process of metakaolinite at about $980^{\circ} \mathrm{C}$, leading to mullite recrystallization, in a similar way than for kaolinite-illite mixtures, since the significant fluxing role of illite [26].

During the structural reorganization at $960^{\circ} \mathrm{C}-980^{\circ} \mathrm{C}$, a first increase of glass from 0 to $10 \mathrm{wt} . \%$ favors a small increase of shrinkage and it is in accordance with the fluxing role of the added waste glass, since the glass viscosity is low at $1100^{\circ} \mathrm{C}\left(\sim 10^{2.5} \mathrm{~Pa} . \mathrm{s}\right)$. But for higher glass $(30-40 \mathrm{wt} . \%)$ and smaller quartz (35 - $\left.30 \mathrm{wt} . \%\right)$ contents, shrinkage at $1100^{\circ} \mathrm{C}$ is reduced and tends to zero. This behavior must be compared to that of the $40 \mathrm{FF}$ sample, which presents a very higher densification at $1100^{\circ} \mathrm{C}$. It shows the kaolinite role which densifies highly at about $980^{\circ} \mathrm{C}$, as for ADI and $40 \mathrm{FF}$ samples, the latter having a higher kaolinite content that increase strongly the densification. When glass to kaolinite ratio increases, glass composition is changed from the diffusion of alumina and silica from the highly reactive metakaolinite. It leads to a strong increase of glass viscosity, according to the VFT model [9], and the possible departure of glass composition away from the glass existence domain. In that way, a slow process of glass recrystallization should occur as it is shown on DRX curve of Figure 5 for 60 wt.\% ADI +40 wt.\% GP, revealing the presence of new anorthite peaks. For this composition and also for $70 \mathrm{wt} . \% \mathrm{ADI}+30 \mathrm{wt} . \% \mathrm{GP}$, it is supposed that kaolinite-glass mixture in the matrix phase between large quartz grains form dense and hard agglomerates by sintering. It is evidenced on Figure 6(c), where the materials microstructure is composed of large quartz grains linked by dense agglomerates, which percolation threshold is attained.

Finally, the mechanical properties under compression depend on microstructural characteristics, i.e. the porosity and the matrix phase nature linking the network of large quartz grains. The glass addition in the clay matrix phase is favorable to grain bringing from glass melting. Nevertheless, local cracks from thermal stress during cooling contribute to the weakening of the macroscopic mechanical strength.

\section{Conclusions}

The large size distribution of both the added glass and quartz, associated with the clay has a key-role in the sintering process. It also involves the three dimensional coarse quartz grains embedded in the clay matrix, whereas the finer quartz fraction is within the clay matrix. The respective characteristics and relative quantities of all phases lead to sintering with limited or zero densification.

The sintering behavior of the studied materials is similar to that of composites where coarse grains form a microstructural skeleton inducing the reduction of the global densification. Microstructural characteristics of zero densification materials are composed of a network of large quartz grains linked by densified agglomerates from clay-glass mixture. Sintered mixture of clay-glass-quartz is a route for the manufacture of low-cost ceramics. It is a useful and an alternative method for manufacturing silicate ceramics when precise and complex shapes are required.

\section{Acknowledgements}

The authors wish to acknowledge the financial assistance provided by the University of Yaounde I (Cameroon) and thank the Scientific and technical staff of ENSCI-GEMH, at the European Centre of Ceramics, Limoges (France) for hosting the investigation of this research project.

\section{References}

[1] Corinaldesia, V., Gnappib, G., Moriconia, G. and Montenerob, A. (2005) Reuse of Ground Waste Glass as Aggregate 
for Mortars. Waste Management, 25, 197-201. http://dx.doi.org/10.1016/j.wasman.2004.12.009

[2] Andreola, F., Barbieri, L., Corradi, A., Lancellotti, I., Falcone, R. and Hreglich, S. (2005) Glass-Ceramics Obtained by the Recycling of End of Life Cathode Ray Tubes Glasses. Waste Management, 25, 183-189. http://dx.doi.org/10.1016/j.wasman.2004.12.007

[3] Loryuenyong, V., Panyachai, T., Kaewsimork, K. and Siritai, C. (2010) Fabrication of Lightweight Clay Bricks from Recycled Glass Wastes. In: Jiang, D., Zeng, Y., Singh, M. and Heinrich, J., Ed., Ceramic Materials and Components for Energy and Environmental Applications, John Wiley \& Sons, Inc., Hoboken, 213-219.

[4] Pontikes, Y., Esposito, L., Tucci, A. and Angelopoulos, G.N. (2007) Thermal Behaviour of Clays for Traditional Ceramics with Soda-Lime-Silica Waste Glass Admixture. Journal of the European Ceramic Society, 27, 1657-1663. http://dx.doi.org/10.1016/i.jeurceramsoc.2006.05.068

[5] Zanelli, C., Raimondo, M., Guarini, G. and Dondi, M. (2011) The Vitreous Phase of Porcelain Stoneware: Composition, Evolution during Sintering and Physical Properties. Journal of Non-Crystalline Solids, 357, 3251-3260. http://dx.doi.org/10.1016/j.jnoncrysol.2011.05.020

[6] Loryuenyong, V., Panyachai, T., Kaewsimork, K. and Siritai, C (2009) Effects of Recycled Glass Substitution on the Physical and Mechanical Properties of Clay Bricks. Waste Management, 29, 2717-2721.

http://dx.doi.org/10.1016/j.wasman.2009.05.015

[7] Binhussaina, M.A., Marangoni,M., Bernardo, E. and Colombo, P. (2014) Sintered and Glazed Glass-Ceramics from Natural and Waste Raw Materials. Ceramics International, 40, 3543-3551. http://dx.doi.org/10.1016/j.ceramint.2013.09.074

[8] Losq, C.L. and Neuville, D.R. (2013) Effect of the Na/K Mixing on the Structure and the Rheology of Tectosilicate Silica-Rich Melts, Chemical Geology, 346, 57-71. http://dx.doi.org/10.1016/j.chemgeo.2012.09.009

[9] Fluegel, A. (2007) Glass Viscosity Calculation Based on a Global Statistical Modelling Approach. European Journal of Glass Science and Technology Part A: Glass Technology, 48, 13-30.

[10] Boccaccini, A.R. (1994) Sintering of Glass Matrix Composites Containing $\mathrm{Al}_{2} \mathrm{O}_{3}$ Platelet Inclusions. Journal of Materials Science, 29, 4273-4278. http://dx.doi.org/10.1007/BF00414210

[11] Boccaccini, A.R. and Olevsky, E.A. (1999) Processing of Platelet-Reinforced Glass Matrix Composites: Effect of Inclusions on Sintering Anisotropy. Journal of Materials Processing Technology, 96, 92-101. http://dx.doi.org/10.1016/S0924-0136(99)00272-1

[12] Tuan W.H., Gilbart, E. and Brook, R.J. (1989) Sintering of Heterogeneous Ceramic Compacts, $\mathrm{Part}^{1} \mathrm{Al}_{2} \mathrm{O}_{3}-\mathrm{Al}_{2} \mathrm{O}_{3}$. Journal of Materials Science, 24, 1062-1068. http://dx.doi.org/10.1007/BF01148799

[13] Tuan, W.H. and Brook R.J. (1989) Sintering of Heterogeneous Ceramic Compacts, Part $2 \mathrm{ZrO}_{2}-\mathrm{Al}_{2} \mathrm{O}_{3}$. Journal of Materials Science, 24, 1953-1958. http://dx.doi.org/10.1007/BF01148799

[14] He, L.H. and Zhao J.H. (2003) Influence of Inclusion Shape on Viscous Sintering. Journal of Non-Crystalline Solids, 316, 384-388. http://dx.doi.org/10.1016/S0022-3093(02)01633-2

[15] Eberstein, M., Reinsch, S., Müller, R., Deubener, J. and Schiller, W.A. (2009) Sintering of Glass Matrix Composites with Small Rigid Inclusions. Journal of the European Ceramic Society, 29, 2469-2479. http://dx.doi.org/10.1016/i.jeurceramsoc.2009.02.007

[16] Azzou, A. and Blanchart, P. (2011) Predicting the Sintering Curve of Porcelain by Support Vector Regression. Journal of the American Ceramic Society, 94, 3768-3773. http://dx.doi.org/10.1111/j.1551-2916.2011.04687.x

[17] Yan, Z., Martin, C.L., Guillon, O. and Bouvard, D. (2013) Effect of Size and Homogeneity of Rigid Inclusions on the Sintering of Composites. Scripta Materialia, 69, 327-330. http://dx.doi.org/10.1016/j.scriptamat.2013.05.013

[18] Huang, R. and Pan J. (2007) A Two-Scale Model for Sintering Damage in Powder Compact Containing Inert Inclusions. Mechanics of Materials, 39, 710-726. http://dx.doi.org/10.1016/j.mechmat.2006.12.002

[19] Ogbukagu, I.N. (1980) Refractory Clays from the Ogwashi-Asaba Formation, South-East Nigeria. Nigeria Field, 45, 76-82.

[20] Fluegel, A. (2004) Glass Viscosity Calculation Based on a Global Statistical Modelling Approach. http://glassproperties.com/

[21] McConcille, C.J., Lee, W.E. and Sharp, J.H. (1998) Microstructure Evolution in Fired Kaolinite. British Ceramic Transactions, 97, 162-167.

[22] Song, J.G., Wang, F., Bai, X.B., Du, D.M., Ju, Y.Y., Xu, M.H. and Ji, G.C. (2011) Effect of the Sintering Technology on the Properties of Fired Brick from Quartz Sands. Journal of Ceramic Processing Research, 12, 357-360.

[23] Djangang, C.N., Elimbi, A., Melo, U.C., Lecomte, G.L., Nkoumbou C., Soro, J., Bonnet J.P., Blanchart, P. and Njopwouo, D. (2008) Refractory Ceramics from Clays of Mayouom and Mvan in Cameroon. Applied Clay Science, 39, $10-$ 18. http://dx.doi.org/10.1016/i.clay.2007.04.006 
[24] Traoré, K., Gridi-Bennadji, F. and Blanchart, P. (2006) Significance of Kinetic Theories on the Recrystallization of Kaolinite, Signicance of Kinetic Theories on the Recrystallization of Kaolinite. Thermochimica Acta, 451, 99-104. http://dx.doi.org/10.1016/j.tca.2006.09.009

[25] Sei, J., Kedi B.A., Olivier-Fourcade, B., Quiquampoix H., Staunton S. and Jumas J.C. (2012) Clays in the Ivory Coast (West Africa): Mineralogy, Physico Chemical Properties and Applications. In: Orbovic, V. and Huang, Z.X., Eds., Kaolinite: Occurrences, Characteristics and Applications, Nova Science Publishers, Hauppauge, 31-67.

[26] Seynou, M., Millogo, Y., Ouedraogo, R., Traoré, K. and Tirlocq, J. (2011) Firing Transformations and Properties of Tiles from a Clay from Burkina Faso. Applied Clay Science, 51, 499-502. http://dx.doi.org/10.1016/j.clay.2011.01.002 
Scientific Research Publishing (SCIRP) is one of the largest Open Access journal publishers. It is currently publishing more than 200 open access, online, peer-reviewed journals covering a wide range of academic disciplines. SCIRP serves the worldwide academic communities and contributes to the progress and application of science with its publication.

Other selected journals from SCIRP are listed as below. Submit your manuscript to us via either submit@scirp.org or Online Submission Portal.
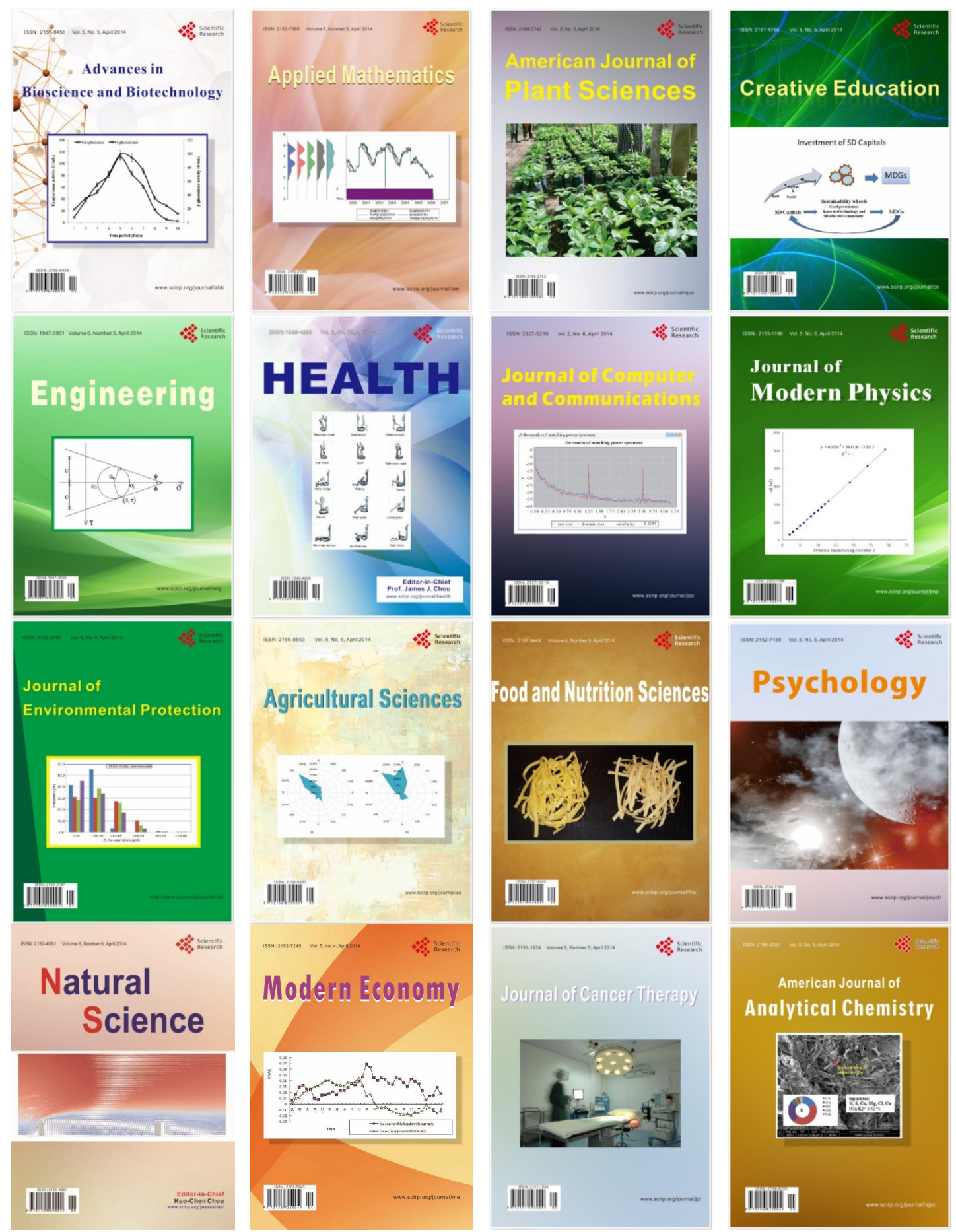